\title{
Oceanography
}

CITATION

Takahashi, T., C. Sweeney, B. Hales, D.W. Chipman, T. Newberger, J.G. Goddard,

R.A. lannuzzi, and S.C. Sutherland. 2012. The changing carbon cycle in the Southern Ocean.

Oceanography 25(3):26-37, http://dx.doi.org/10.5670/oceanog.2012.71.

DOI

http://dx.doi.org/10.5670/oceanog.2012.71

COPYRIGHT

This article has been published in Oceanography, Volume 25, Number 3, a quarterly journal of The Oceanography Society. Copyright 2012 by The Oceanography Society. All rights reserved.

USAGE

Permission is granted to copy this article for use in teaching and research. Republication, systematic reproduction, or collective redistribution of any portion of this article by photocopy machine, reposting, or other means is permitted only with the approval of The Oceanography Society. Send all correspondence to: info@tos.org or The Oceanography Society, PO Box 1931, Rockville, MD 20849-1931, USA. 


\section{THE CHANGING \\ CARBON CYCLE IN THE SOUTHERN OCEAN}

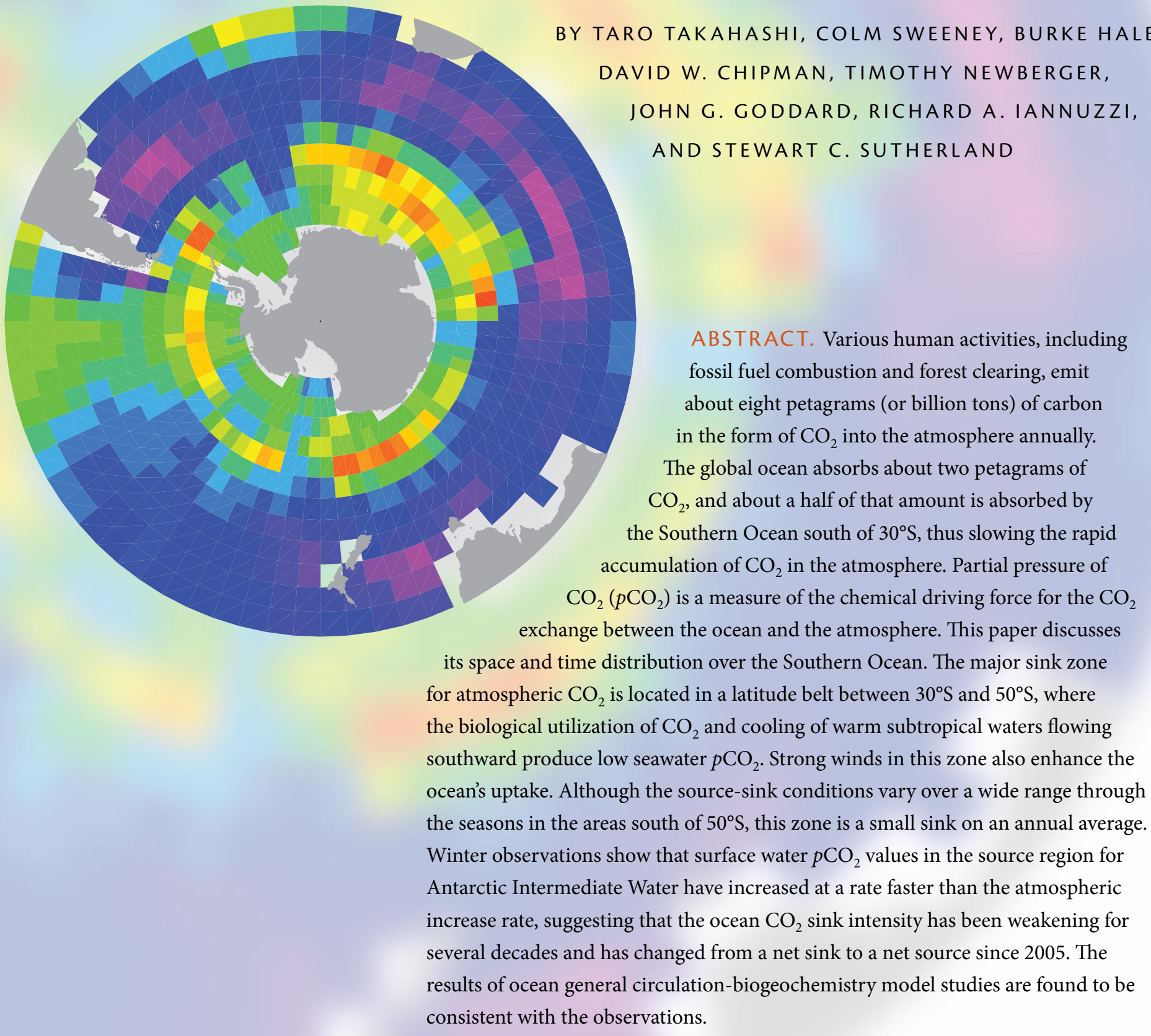




\section{INTRODUCTION}

The Southern Ocean is a major region for the formation of deepwater masses that fill the ocean basins, and it is an important conduit for exchange of heat, momentum, and dissolved gases between the atmosphere and the ocean interior. The global ocean is currently absorbing annually about $2 \mathrm{Pg}$ of carbon ( $1 \mathrm{Pg}=$ 1 petagram $=10^{15}$ grams $=1$ billion tons) from the air in the form of $\mathrm{CO}_{2}$ gas, and the Southern Ocean south of $30^{\circ} \mathrm{S}$ takes up about $1 \mathrm{Pg}$ of carbon. Thus, the Southern Ocean's significant role in the uptake and long-term storage of anthropogenic $\mathrm{CO}_{2}$ emitted to the atmosphere affects Earth's climate.

The difference between the partial pressure of $\mathrm{CO}_{2}\left(p \mathrm{CO}_{2}\right)$ in seawater and that in the overlying air determines the direction of $\mathrm{CO}_{2}$ transfer across the sea surface. Two opposing processes primarily govern $\mathrm{CO}_{2}$ chemistry in seawater: sinking of biological products from the photic zone to deep-ocean regimes (i.e., the biological pump), and upward transport by upwelling deep waters of $\mathrm{CO}_{2}$ and nutrients formed by the decomposition of biological debris. Thus, understanding the ocean's uptake rates of atmospheric $\mathrm{CO}_{2}$ requires knowledge of ocean circulation dynamics as well as production and respiration dynamics in a wide range of ecosystems. A large number of observational and model studies have been conducted in recent years. The observational studies are based on the sea-air $p \mathrm{CO}_{2}$ difference (Takahashi et al., 2009), ${ }^{13} \mathrm{C} /{ }^{12} \mathrm{C}$ mass balance (Quay et al., 2003), atmospheric oxygen and $\mathrm{CO}_{2}$ changes (Bender et al., 2005; Manning and Keeling, 2006), and $\mathrm{CO}_{2}$ change in the ocean (Sabine et al., 2004). The model studies include coupled Ocean
General Circulation-Biogeochemistry models (OGCM) (Mikaloff-Fletcher et al., 2006; Sarmiento and Gruber, 2006; Jacobson et al., 2007; Lenton and Matear, 2007; Gruber et al., 2009; Le Quérér et al., 2010), and inversion of atmospheric $\mathrm{CO}_{2}$ data using Atmospheric General Circulation models (AGCM) (Gurney et al., 2008). Gruber et al. (2009) reviewed the estimates for $\mathrm{CO}_{2}$ uptake flux over the contemporary global ocean obtained by four groups of independent methods: inversion of the ocean data using 10 OGCMs, 13 ocean forward models (OCMIP-2), inversion of atmospheric $\mathrm{CO}_{2}$ data (Gurney et al., 2008), and sea-air $p \mathrm{CO}_{2}$ difference (Takahashi et al., 2009). Although the mean air-to-sea flux estimates for the contemporary global ocean obtained by these methods are in general agreement at $1.5 \pm 0.5 \mathrm{Pg} \mathrm{C} \mathrm{yr}^{-1}$, notable discrepancies are found in the Southern Ocean. The ocean inversion methods suggest a relatively uniform weak sink in the areas south of $58^{\circ} \mathrm{S}$, whereas the sea-air $p \mathrm{CO}_{2}$ difference $\left(\triangle p \mathrm{CO}_{2}\right)$ data in these areas suggest a $\mathrm{CO}_{2}$ source. Processes governing atmosphere-ocean interactions in the Southern Ocean region are complex because of the large seasonal variability in temperature, wind regimes, ice/water conditions, and biological activities. Although significant progress has been made in recent years due to improved research facilities, observations are still limited because of operational difficulties related to hostile weather conditions, and observation-based estimates are subject to considerable uncertainty. Model results are also subject to uncertainties because of limited time-space resolutions and imperfections in the parameterizations for various processes, including eddy mixing, ice formation, and biological processes.

In this article, we review recent progress in biogeochemical studies on the carbon cycle with emphasis on the temporal and spatial variability of $p \mathrm{CO}_{2}$ in Southern Ocean surface water. Here, the Southern Ocean is defined as the oceanic areas south of $30^{\circ} \mathrm{S}$ that include a major sink zone for atmospheric $\mathrm{CO}_{2}$ centered at $40^{\circ} \mathrm{S}$. First, we review climatological mean distribution of surface water $\mathrm{pCO}_{2}$ and net sea-air $\mathrm{CO}_{2}$ flux. Second, we discuss the change in surface water $p \mathrm{CO}_{2}$ and the intensity of the ocean $\mathrm{CO}_{2}$ sink in circumpolar waters.
Taro Takahashi (taka@ldeo.columbia.edu) is Ewing Lamont Research Professor, LamontDoherty Earth Observatory of Columbia University, Palisades, NY, USA. Colm Sweeney is CIRES Research Scientist, Cooperative Research Institute in Environmental Sciences (CIRES), University of Colorado, Boulder, CO, USA. Burke Hales is Professor, College of Oceanic and Atmospheric Sciences, Oregon State University, Corvallis, OR, USA. David W. Chipman is retired from the Lamont-Doherty Earth Observatory of Columbia University, Palisades, NY, USA. Timothy Newberger is Associate, CIRES, University of Colorado, Boulder, CO, USA. John G. Goddard provides marine technical assistance for the Lamont-Doherty Earth Observatory of Columbia University, Palisades, NY, USA. Richard A. lannuzzi is Intermediate Systems Analyst/Programmer, Lamont-Doherty Earth Observatory of Columbia University, Palisades, NY, USA. Stewart C. Sutherland is Research Staff Scientist, Lamont-Doherty Earth Observatory of Columbia University, Palisades, NY, USA. 


\section{SEA-AIR $\mathrm{CO}_{2}$ TRANSFER OVER}

\section{THE SOUTHERN OCEAN}

Before we discuss $\mathrm{CO}_{2}$ exchange over the Southern Ocean, we briefly review relevant oceanographic information. Because $p \mathrm{CO}_{2}$ is the primary quantity measured by our group, we next discuss the time-space distribution of surface water $p \mathrm{CO}_{2}$, and then present the net sea-air $\mathrm{CO}_{2}$ flux.

\section{General Structure of the}

\section{Upper Waters}

The oceanographic features in the Southern Ocean are primarily zonal due to strong, persistent westerly winds blowing around the Antarctic Continent. Several oceanographically distinct zones are separated by fronts where water properties change (Orsi et al., 1995): from north to south, these are the Subtropical Front (STF), the Subantarctic Front (SAF), the Polar Front (PF), the
Antarctic Divergence (AD), and the Continental Water Boundary (CWB). The Antarctic Circumpolar Current (ACC) includes the waters south of STF and north of CWB. Figure 1a shows the approximate positions of these fronts. In the high-latitude areas $\left(60^{\circ} \mathrm{S}-70^{\circ} \mathrm{S}\right)$, high-salinity water (Lower Circumpolar Deep Water, LCDW, with a salinity of 34.68) upwells along the Antarctic Divergence (AD). As the upwelled water drifts northward, it is altered by exchange with air, and it is subducted along the Polar Front (PF; $50^{\circ} \mathrm{S}-60^{\circ} \mathrm{S}$ ). In general, high-latitude Southern Ocean surface waters are high in nutrients and $\mathrm{CO}_{2}$ but low in chlorophyll concentrations (called HNLC conditions), with the exception of local waters in the coastal zone around Antarctica. The high concentrations of nutrients and $\mathrm{CO}_{2}$ are due to the wintertime convective mixing of Upper Circumpolar Deep Water (UCDW) rich in $\mathrm{CO}_{2}$ and nutrients as well as northward Ekman transport of the upwelled deep waters. In the vicinity of the SubAntarctic front (SAF; $50^{\circ} \mathrm{S}-55^{\circ} \mathrm{S}$ ), lowsalinity Intermediate Water (AAIW, temperatures $3^{\circ}-5^{\circ} \mathrm{C}$, salinity about 34.3 ) is formed and sinks to the base of the main thermocline ( $900 \mathrm{~m}$ deep). Further north, along the Subtropical Front $\left(\sim 40^{\circ} \mathrm{S}\right)$, the sub-Antarctic surface water that is replete with nutrients but low in chlorophyll (i.e., HNLC) converges with warm subtropical surface water that is depleted in nutrients. In the resulting high primary productivity zone that is clearly visible in satellite color images (Moore and Abbott, 2000), surface water $p \mathrm{CO}_{2}$ is reduced, creating a strong $\mathrm{CO}_{2}$ sink zone centered around $40^{\circ} \mathrm{S}$ in the Atlantic, Indian, and most of the Pacific Oceans. These waters (Mode Water) sink to mid-depth and transport atmospheric $\mathrm{CO}_{2}$ to the subsurface regime.
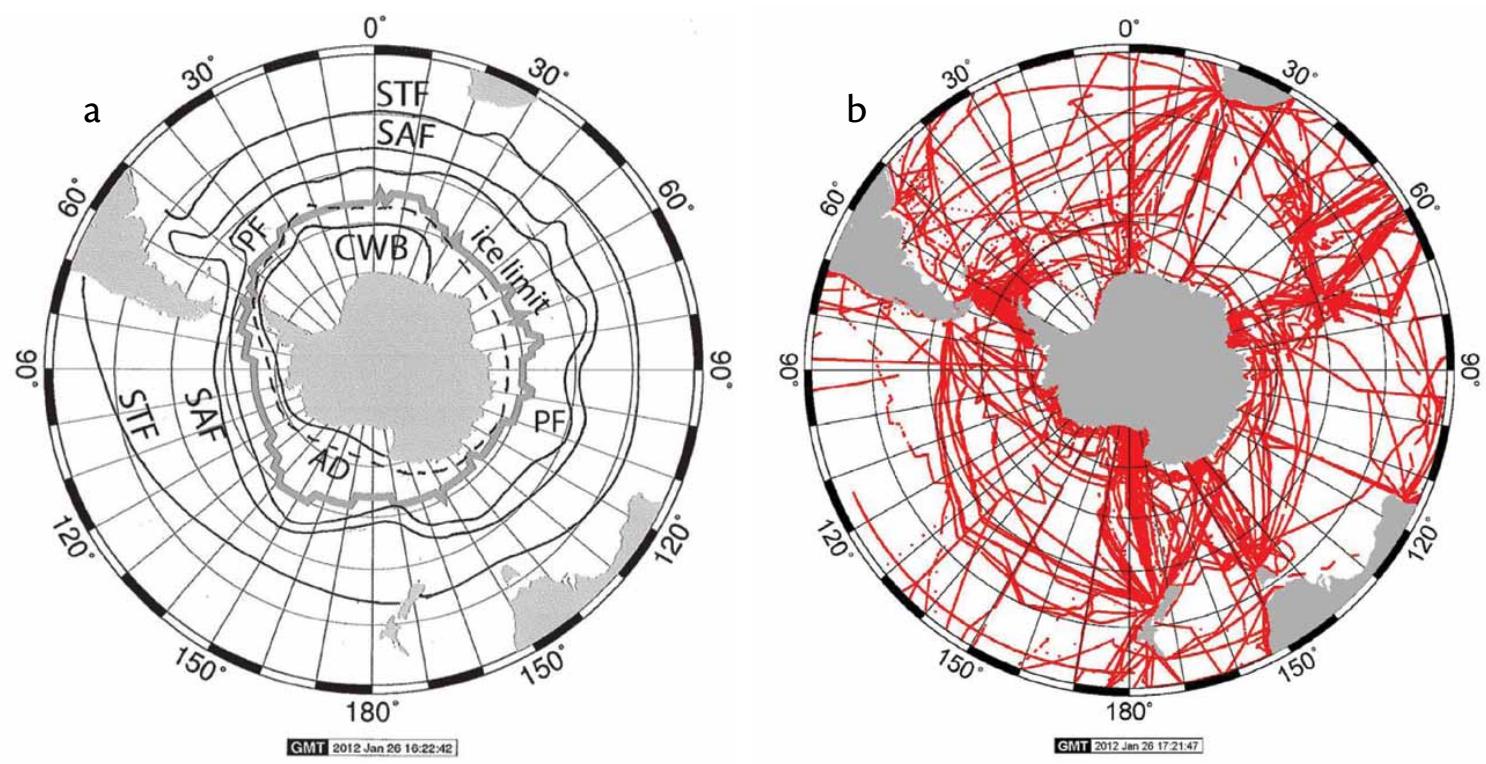

Figure 1. (a) Zonal structure of Southern Ocean surface waters (based on Orsi et al., 1995), showing the approximate locations of fronts: STF = Subtropical Front. SAF = Subantarctic front. PF = Polar Front. AD = Antarctic Divergence. $\mathrm{CWB}=$ Continental Water Boundary. Winter ice limit is indicated with a broad gray curve. (b) Locations of surface water $p \mathrm{CO}_{2}$ measurements between 1960 and 2011 over the Southern Ocean. Approximately 2.1 million $p \mathrm{CO}_{2}$ measurements were made during this period; the data (Takahashi et al., 2011) are available at the Carbon Dioxide Information and Analysis Center at Oak Ridge National Laboratory (CDIAC; http://cdiac.ornl.gov/oceans/LDEO_Underway_Database). 
$\mathrm{CO}_{2}$ Partial Pressure in

Surface Water

In seawater, $\mathrm{CO}_{2}$ molecules exist in three forms: as $\mathrm{CO}_{2}$ molecules in an aqueous environment $\left(\left[\mathrm{CO}_{2}\right]_{\mathrm{aq}}\right.$ or $\left.\left[\mathrm{H}_{2} \mathrm{CO}_{3}\right]\right)$ and as two ionized forms ([ $\left.\mathrm{HCO}_{3}^{-}\right]$ and $\left.\left[\mathrm{CO}_{3}^{=}\right]\right)$. The sum of these species is referred to as the total concentration of $\mathrm{CO}_{2}$ dissolved in seawater $\left(\mathrm{TCO}_{2}\right)$, which is measured as the total amount of $\mathrm{CO}_{2}$ extracted from an acidified seawater sample. In surface ocean waters, about $1 \%$ of $\mathrm{TCO}_{2}$ exists as $\left[\mathrm{CO}_{2}\right]_{\mathrm{aq}}$, about $4 \%$ as $\left[\mathrm{CO}_{3}^{=}\right]$, and $95 \%$ as $\left[\mathrm{HCO}_{3}^{-}\right]$. Of these, $\left[\mathrm{CO}_{2}\right]_{\mathrm{aq}}$ is the only species involved in the exchange of $\mathrm{CO}_{2}$ between the sea and the overlying air. The partial pressure of seawater $\mathrm{CO}_{2}$ is a measure of $\left[\mathrm{CO}_{2}\right]_{\mathrm{aq}}$, and represents the driving force for the transfer of $\mathrm{CO}_{2}$ gas across the sea-air interface. The difference between $p \mathrm{CO}_{2}$ in seawater and air $\left(\Delta p \mathrm{CO}_{2}\right)$ determines the direction and magnitude of the net $\mathrm{CO}_{2}$ flux across the interface. When the $p \mathrm{CO}_{2}$ in seawater is greater than that in the overlying air $\left(\Delta p \mathrm{CO}_{2}>0\right)$, the net flux is from sea to air; when $\Delta p \mathrm{CO}_{2}$ $<0$, the net flux is from air to sea. The net sea-air flux may be estimated by multiplying the sea-air $p \mathrm{CO}_{2}$ difference by the gas transfer coefficient across the sea surface.

\section{Observations of Surface} Water $p \mathrm{CO}_{2}$

Figure $1 \mathrm{~b}$ shows the locations of where surface water $p \mathrm{CO}_{2}$ data have been collected over the Southern Ocean since the 1960s. The observations were made using a gas-seawater equilibrator coupled with a $\mathrm{CO}_{2}$ analyzer (gas chromatograph or IR analyzer) that was calibrated using three or more certified $\mathrm{CO}_{2}$-air reference gas mixtures by the Climate Monitoring and Diagnostics Laboratory of the National Oceanic and Atmospheric Administration (NOAA), Boulder, CO. Equilibrators (bubbler, membrane, or shower types; e.g., Chipman et al., 1993; Hales et al., 2004; Newberger, 2004) were operated either in a seawater flowthrough mode for continuous underway measurement of water samples pumped from an intake located a few meters below the sea surface, or in a discrete water mode for water samples collected in nonmetallic sampling bottles. Seawater temperature and salinity and equilibration pressure and temperature are recorded and used for computing in situ $p \mathrm{CO}_{2}$ values. The overall precision of the $p \mathrm{CO}_{2}$ data is estimated to be $\pm 2 \mu$ atm.

\section{Climatological Mean Distribution} of Surface Water $\mathrm{pCO}_{2}$

Figure 2 displays monthly distribution maps for the climatological mean seaair $\mathrm{pCO}_{2}$ difference for the reference year 2000. Here, we briefly describe the method used for constructing these maps. Because $p \mathrm{CO}_{2}$ has increased with time in response to the increase in atmospheric $\mathrm{CO}_{2}$, data obtained in different years and months are corrected to a reference year 2000 using a mean rate

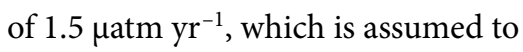
be equal to the mean atmospheric $\mathrm{CO}_{2}$ increase. The corrected $p \mathrm{CO}_{2}$ values are binned into $4^{\circ} \times 5^{\circ}$ boxes, and monthly mean values for each box are computed. Because fewer than $50 \%$ of the boxes have observations, they are interpolated using a two-dimensional diffusionadvection transport equation to fill all the boxes. The sea-air $p \mathrm{CO}_{2}$ differences $\left(\triangle p \mathrm{CO}_{2}\right)$ are computed using atmospheric $p \mathrm{CO}_{2}$ values that are calculated from zonal mean atmospheric $\mathrm{CO}_{2}$ concentrations in dry air for the year 2000 (GLOBALVIEW, 2006) and monthly mean values for barometric pressure and water vapor pressure at the sea surface. The computational details are described in Takahashi et al. (2009), and the climatological mean values in each box are available at http://www.ldeo.columbia. edu/res/pi/CO2.

Figure 2 shows that a strong $\mathrm{CO}_{2}$ sink zone (blue color with negative $\Delta p \mathrm{CO}_{2}$ ) is located near $40^{\circ} \mathrm{S}$ during the austral winter months (June through October). Its formation is attributed primarily to high productivity in the high-chlorophyll zone observed by satellites over the same latitudes (see Plates 3 and 6 in Moore and Abbott, 2000). However, the colocation of the $\mathrm{CO}_{2}$ sink zone and the high-productivity zone is only qualitative because seawater $p \mathrm{CO}_{2}$ is governed by net community production, which includes primary production as well as the respiration, recycling, and export of organic carbon from the mixed layer. Peaking of the sink intensity in August and September suggests that winter cooling of surface water plays an important role in the formation of the sink. As the season progresses, the $\mathrm{CO}_{2}$ sink zone moves southward due mainly to increased photosynthesis under longer daylight hours and warmer temperatures. The biological drawdown effect is clearly seen in the areas north of the Weddell and Ross Seas, where satellites observe high concentrations of chlorophyll (see Plate 3 of Moore and Abbott, 2000). Boutin et al. (2008) measured sea-air $p \mathrm{CO}_{2}$ difference continuously in the zone between the PF and the SAF $\left(40^{\circ} \mathrm{S}-55^{\circ} \mathrm{S}\right)$ in the Pacific and Indian Ocean sectors using the CARIOCA 
(Carbon Interface Ocean Atmosphere) drifter buoys during all seasons from 2001 to 2006, observing that the waters in these areas are mostly undersaturated with a mean $\Delta p \mathrm{CO}_{2}$ of $-19 \mu \mathrm{atm}$. Their mean value is similar to our climatological mean within about $2 \mu \mathrm{atm}$.

In the permanently open ocean zone
(POOZ) of the ACC between $50^{\circ} \mathrm{S}$ and $60^{\circ} \mathrm{S}, \Delta p \mathrm{CO}_{2}$ is generally small (light blue and green in Figure 2) because of the competing effects of temperature and $\mathrm{TCO}_{2}$ on seawater $p \mathrm{CO}_{2}$ : summertime photosynthesis reduces $\mathrm{TCO}_{2}$ and $p \mathrm{CO}_{2}$, counteracting $p \mathrm{CO}_{2}$ increase due to warming, whereas wintertime cooling counteracts the increasing effect on $\mathrm{pCO}_{2}$ of upwelled high $\mathrm{TCO}_{2}$ deep waters. In the Indian Ocean sector between $50^{\circ} \mathrm{S}$ and $58^{\circ} \mathrm{S}$, Metzl et al. (2006) measured $p \mathrm{CO}_{2}, \mathrm{TCO}_{2}$, alkalinity, and the concentrations of chlorophyll, silicate, and nitrate during January and August cruises in
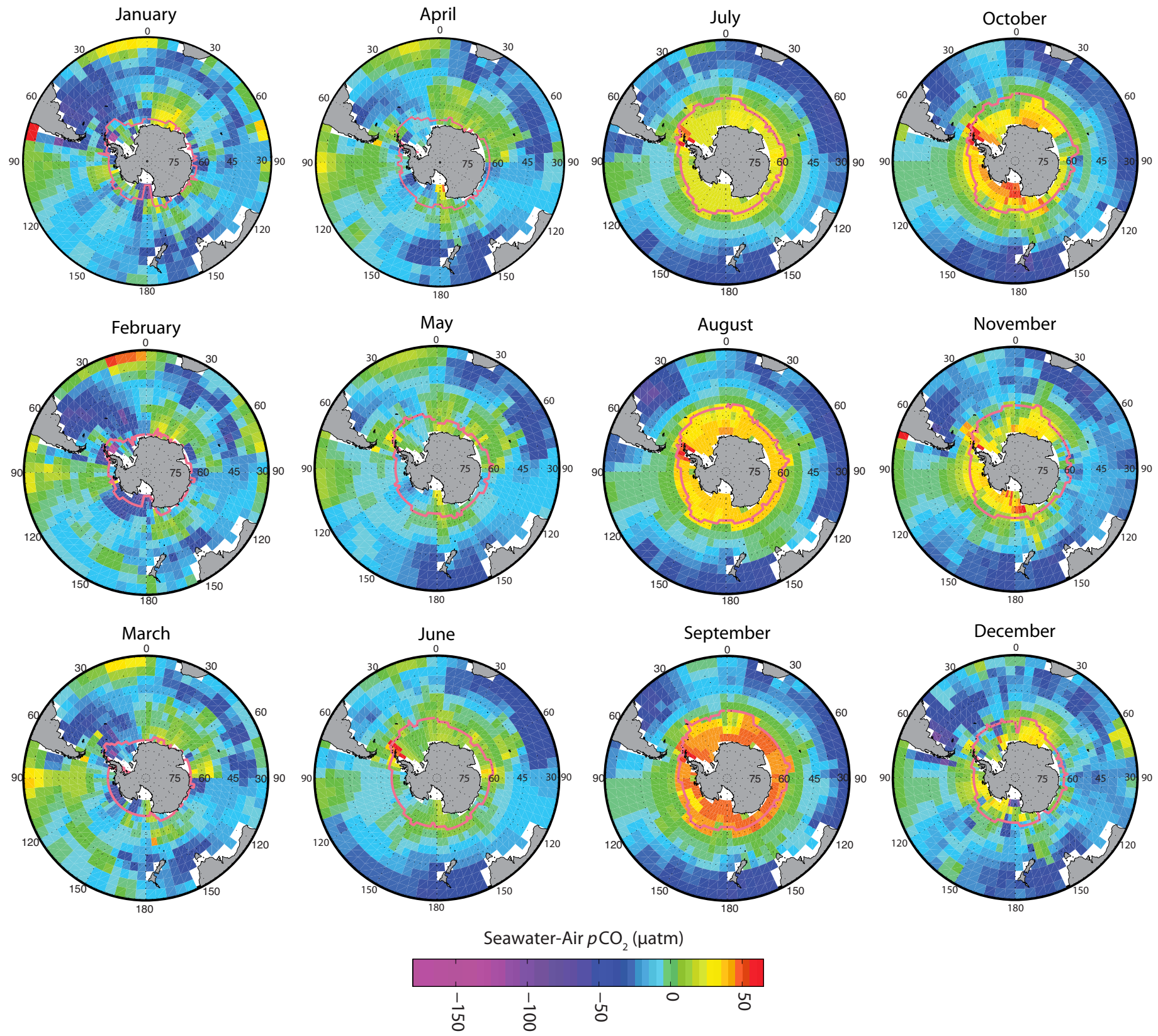

Figure 2. Monthly distribution maps for the climatological mean sea-air $\mathrm{pCO}_{2}$ difference ( $\mu$ atm) for the reference year 2000 . The pink curves indicate the approximate locations of the northern edges of ice fields, and hence define the seasonal ice zone. The high $p \mathrm{CO}_{2}$ values in the under-ice mixed layer are due to the upward mixing of high $\mathrm{CO}_{2}$ Upper Circumpolar Deep Water. 
2000, observing that the summertime seawater $\mathrm{PCO}_{2}$ was lower than the atmospheric $p \mathrm{CO}_{2}\left(\Delta p \mathrm{CO}_{2} \sim-15 \mu \mathrm{atm}\right)$ due to photosynthesis, and the winter $p \mathrm{CO}_{2}$ was higher than the atmospheric $\left(\Delta p \mathrm{CO}_{2} \sim+10 \mu \mathrm{atm}\right)$ due to the upwelling of high- $\mathrm{CO}_{2}$ deep waters. Because the alkalinity was found to be similar, the biological effect on $\mathrm{CO}_{2}$ is due mostly to the production of organic carbon.

In the seasonal ice zone (SIZ, south of $\sim 60^{\circ} \mathrm{S}$, poleward of the "ice limit" curve in Figure 1 and poleward of the pink curves in Figure 2), the seawater in autumn has low $p \mathrm{CO}_{2}$ values because of biological utilization during the preceding season. As the sea ice field develops, a mixed layer of seawater forms under the ice field, and its $\mathrm{CO}_{2}$ and nutrient concentrations increase as deep waters are mixed into it as the seasons progress. As Figure 3 shows, the $p \mathrm{CO}_{2}$ in ice field waters is low $(\sim 340 \mu \mathrm{atm})$ soon after the formation of the ice in June (day 170), and it increases during the progressing winter season to

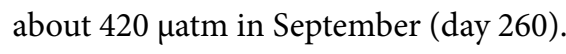
Although algae grow in the basal zone of sea ice, their photosynthetic utilization of $\mathrm{CO}_{2}$ is slow because of low light conditions due to winter darkness and ice-snow cover (Lizotte, 2001; Arrigo and Thomas, 2004), and it does not significantly reduce the large amount of $\mathrm{CO}_{2}$ dissolved in a thick under-ice mixed layer. From mid-July through September, $p \mathrm{CO}_{2}$ in the under-ice waters exceeds the atmospheric $p \mathrm{CO}_{2}$, and therefore, the under-ice water $\mathrm{CO}_{2}$ is released to the air when the water is exposed to the air. In the early spring, as sea ice fields start to break up, the water in the marginal ice zone (MIZ) should be a $\mathrm{CO}_{2}$ source. When the winter sea ice thins and melts away in the spring, phytoplankton blooms, fueled by high nutrient concentrations, reduce the $\mathrm{pCO}_{2}$ in water, and the water rapidly becomes a sink for atmospheric $\mathrm{CO}_{2}$, as Bakker et al. (2008) observe in the Weddell Sea area. The transition from $\mathrm{CO}_{2}$ source to sink occurs as the ice fields retreat in the spring, sweeping across the $15 \times 10^{6} \mathrm{~km}^{2}$ SIZ of the Southern Ocean.

The coastal waters reflect the properties of upwelled waters modified by complex shelf processes, and they regulate the transport of atmospheric $\mathrm{CO}_{2}$ into the deep and abyssal regimes (see Takahashi and Chipman, 2012, in this issue). In summer, the Ross and Weddell Seas and the coastal waters in the Amundsen and Bellingshausen Seas are strong $\mathrm{CO}_{2}$ sinks with $p \mathrm{CO}_{2}$ values as low as $170 \mu$ atm $(\sim 210 \mu$ atm below the air $\left.p \mathrm{CO}_{2}\right)$ due to intense photosynthesis, whereas they are a strong source during winter with $p \mathrm{CO}_{2}$ as high as $425 \mu$ atm $\left(\sim 45 \mu\right.$ atm above the present air $\left.p \mathrm{CO}_{2}\right)$ due to upwelling of high- $\mathrm{CO}_{2}$ deep waters (Bakker et al., 1997, 2008; Bates et al., 1998; Rubin et al., 1998; Sweeney, 2003; Hales and Takahashi, 2004; Rubin, 2003; Arrigo and van Dijken, 2007).

Net Sea-Air $\mathrm{CO}_{2}$ Flux from $\triangle p \mathrm{CO}_{2}$ The net $\mathrm{CO}_{2}$ flux across the sea surface $\left(F_{\text {sea-air }}\right)$ may be estimated by Equation 1, in which the main drivers are wind speed and sea-air $p \mathrm{CO}_{2}$ difference $\left(\Delta p \mathrm{CO}_{2}\right)$ :

$F_{\text {sea-air }}\left(\mathrm{g} \mathrm{C} \mathrm{m}^{-2} \mathrm{month}^{-1}\right)=$ $0.585 \cdot \mathrm{Ko} \cdot(\mathrm{Sc})^{-1 / 2} \cdot\left(\mathrm{U}_{10}\right)^{2} \cdot \Delta p \mathrm{CO}_{2}$,

where $\mathrm{Ko}$ is the solubility of $\mathrm{CO}_{2}$ in seawater $\left(\mathrm{mol} \mathrm{CO}_{2}\right.$ liter $^{-1} \mathrm{~atm}^{-1}$; Weiss, 1974), Sc is the Schmidt number (see Wanninkhof, 1992), $\mathrm{U}_{10}\left(\mathrm{~m} \mathrm{sec}^{-1}\right)$ is the wind speed at $10 \mathrm{~m}$ above the sea surface, and $\Delta p \mathrm{CO}_{2}$ is in $\mu$ atm. The number 0.585 includes a unit conversion factor (changes from second to month, from liter to $\mathrm{m}^{3}$ ), the gas

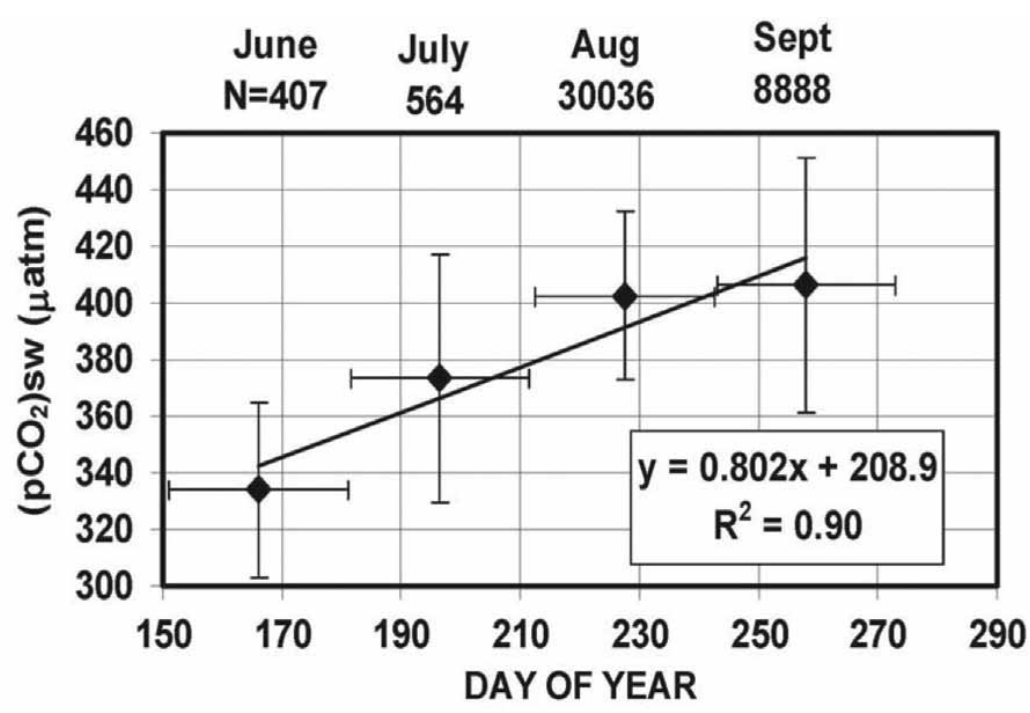

Figure 3. Seawater $p \mathrm{CO}_{2}$ observed in ice field waters with temperatures less than $-1.75^{\circ} \mathrm{C}$ in areas south of $60^{\circ} \mathrm{S}$ during June to September since 1998 . The measurements were made possible by improvements in the intake port for the scientific water sampling line aboard RVIB Nathaniel B. Palmer that prevent ice clogging. The data obtained in different years are averaged for each month, and one standard deviation is shown. The $p \mathrm{CO}_{2}$ in under-ice water increases as the season progresses. From Takahashi et al. (2009) 
transfer scaling factor of 0.26 , and the reference Schmidt number of $(660)^{1 / 2}$ at $20^{\circ} \mathrm{C}$ for seawater (Takahashi et al., 2009). Although Ko and Sc vary with temperature, the temperature effects cancel in the ratio, and $\mathrm{Ko} /(\mathrm{Sc})^{1 / 2}$ is nearly constant in the ocean temperature range. The $0.26( \pm 30 \%)$ scaling factor for the gas transfer rate is determined using the bomb carbon-14 data with the Geophysical Fluid Dynamics Laboratory Ocean General Circulation Model (GFDL OGCM; Sweeney et al., 2007) specifically for the 1979-2005 NCEP-DOE AMIP-II Reanalysis sixhour wind data (Kanamitsu et al., 2002), which are used in this study. Several wind speed products are available for the global ocean, and they vary considerably. Hence, the estimated flux varies by about $20 \%$, depending on the wind speed product used (Signorini and McClain, 2009).

\section{Climatological Mean}

Sea-Air $\mathrm{CO}_{2}$ Flux

Figure 4 shows the meridional distribution of climatological mean $\mathrm{CO}_{2}$ flux over the global ocean in the reference year 2000, which yields a net global ocean $\mathrm{CO}_{2}$ uptake flux of $1.6 \pm 0.7 \mathrm{Pg} \mathrm{C} \mathrm{yr}^{-1}$. Although the flux uncertainty from the error in $\triangle p \mathrm{CO}_{2}$ is relatively small (13\%), the errors in the scaling factor for the gas transfer rate formula $( \pm 30 \%)$ and the wind speed variability $( \pm 20 \%)$ are major contributors to the flux uncertainty (Takahashi et al., 2009). The equatorial waters are the major $\mathrm{CO}_{2}$ source of about $0.7 \mathrm{Pg} \mathrm{C} \mathrm{yr}^{-1}$. This source is counteracted by the two major sinks: a 1.0 $\mathrm{Pg} \mathrm{C} \mathrm{yr}^{-1}$ sink centered around $40^{\circ} \mathrm{S}$ in the Southern Hemisphere and a $0.7 \mathrm{Pg} \mathrm{C} \mathrm{yr}^{-1}$ sink centered around $40^{\circ} \mathrm{N}$ in the Northern Hemisphere. Thus, the Southern Ocean plays a significant

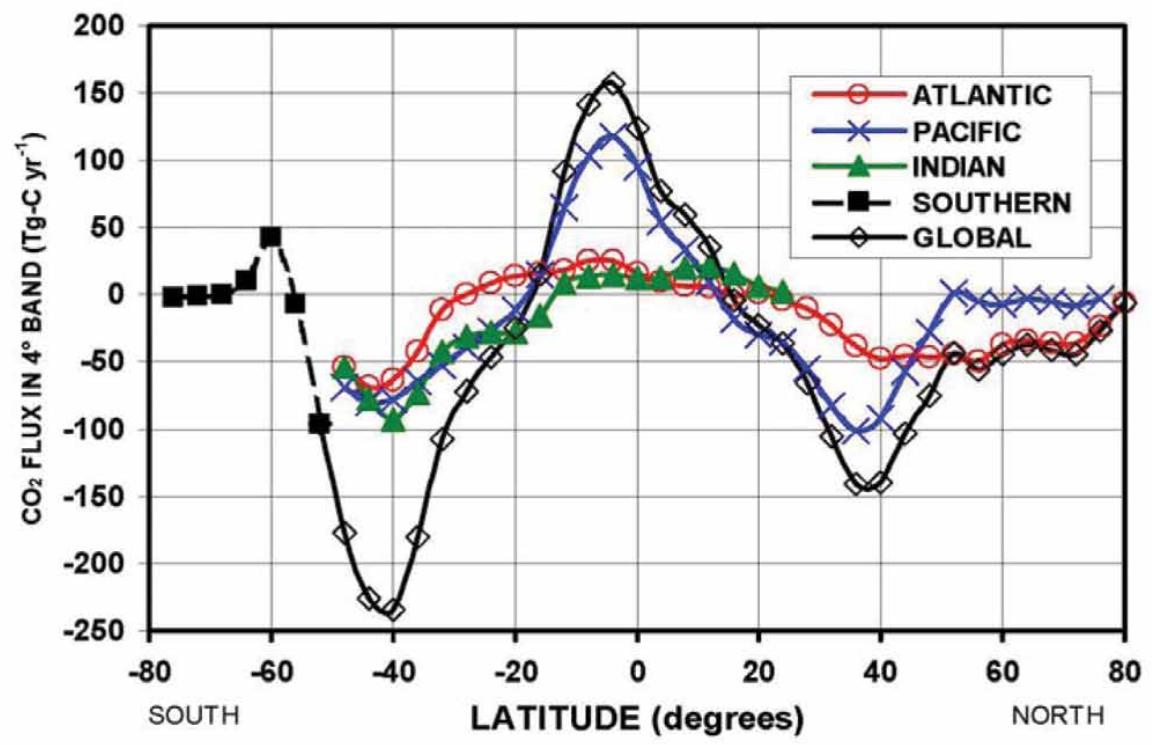

Figure 4. Climatological mean sea-air $\mathrm{CO}_{2}$ flux in $4^{\circ}$ zonal bands in the four major ocean

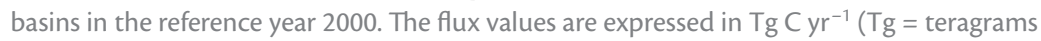
$=10^{12}$ grams $=$ million tons) for each $4^{\circ}$-wide zonal band across each ocean basin. This plot gives a total global air-to-sea flux of $1.6 \mathrm{Pg} \mathrm{C} \mathrm{yr}^{-1}$. The wind speed data are from the 1979-2005 NCEP-DOE AMIP-II Reanalysis, and the gas transfer coefficient is computed using Equation 1. From Takahashi et al. (2009)

role in the global ocean $\mathrm{CO}_{2}$ cycle.

Figure 5 shows the climatological mean distributions of $\mathrm{CO}_{2}$ flux for February and August, and the annual average in the reference year 2000 . During the austral summer (February), a belt of strong sink is centered around $45^{\circ} \mathrm{S}$. This sink is especially robust in the Atlantic sector, perhaps due to intense mixing caused by rough topography and the confluence of warm subtropical and nutrient rich sub-Antarctic waters. Shallow mixed layers in this area (Dong et al., 2008) also enhance the effect of biological drawdown. Intense sink areas are also found in the Ross Sea gyre area, attributed primarily to biological drawdown of $p \mathrm{CO}_{2}$ fueled by abundant nutrients and sunlight. The zones south of about $50^{\circ} \mathrm{S}$ and north of about $40^{\circ} \mathrm{S}$ are neutral (green) or weak source areas (yellow), reflecting the small $\Delta p \mathrm{CO}_{2}$ that results from compensating effects of warming and increased biological $\mathrm{CO}_{2}$ utilization.

During the austral winter (August), wind intensifies and water cools, causing the sink zone centered around $40^{\circ} \mathrm{S}$ to intensify. The gas transfer rate is increased as a square function of wind speed (Equation 1), and the cooling reduces surface water $p \mathrm{CO}_{2}$, although these effects are partially compensated by the increased $p \mathrm{CO}_{2}$ of upwelling of deep waters. The neutral zone (green) south of the sink zone expands, perhaps due to the increase in deepwater upwelling. In the sea ice zone south of about $55^{\circ} \mathrm{S}$, the seaair $\mathrm{CO}_{2}$ flux is computed assuming that a layer of solid ice blocks gas exchange and that sea-air gas exchange takes place only through open water areas in ice fields. For the open water areas, the $\mathrm{CO}_{2}$ flux is computed using Equation 1, in 
which the $\Delta p \mathrm{CO}_{2}$ is represented by ice field measurements shown in Figure 3. In June, the $\Delta p \mathrm{CO}_{2}$ in under-ice waters is negative, reflecting the low $p \mathrm{CO}_{2}$ conditions produced by the biological pump during the preceding months. Hence, when water is exposed to the air, it acts as a sink for atmospheric $\mathrm{CO}_{2}$, and as the season progresses, it becomes a source by July. For the ice field surrounding the continent, the NCEP/DOE 2 Reanalysis (2005) ice cover data are regridded to our $4^{\circ} \times 5^{\circ}$ grid and averaged for each month. When the ice cover is less than $10 \%$ in a $4^{\circ} \times 5^{\circ}$ box area, it is assumed to be all water. Between $10 \%$ and $90 \%$, the flux is computed proportional to the water area. Because ice fields have leads and polynyas due to dynamic motion of sea ice, we assume the fields to be $10 \%$ open water even though the satellite data report $100 \%$ ice cover (Worby et al., 2008). The strong $\mathrm{CO}_{2}$ source zone centered around $60^{\circ} \mathrm{S}$ (yellow-orange) reflects the ice field edge zone in late winter months, when a large area of seawater with positive $\Delta p \mathrm{CO}_{2}$ values is exposed to the air, allowing gas exchange. Although the seasonal ice zone exhibits large seasonal changes in physical, biological, and chemical conditions, this zone appears to make a small contribution in terms of annual sea-air $\mathrm{CO}_{2}$ flux to the global sea-air $\mathrm{CO}_{2}$ budget.

On the annual mean, the zone centered around $40^{\circ} \mathrm{S}$ (magenta-blue; sea surface temperature [SST] between $10^{\circ} \mathrm{C}$ and $15^{\circ} \mathrm{C}$ ) stands out as a prominent sink for the global sea-air carbon budget. To investigate Southern Ocean $\mathrm{CO}_{2}$ uptake and its relationship to the Southern Annular Mode (SAM), Lovenduski et al. (2007) used the forward Parallel Ocean Program Ocean GCM coupled with a biogeochemical-ecological model. They found strong $\mathrm{CO}_{2}$ sink zones centered around $40^{\circ} \mathrm{S}$, and they determined that the sink in the Atlantic and the western Indian Ocean sectors were most intense and the southeastern Pacific less so. Their model results for the distribution and magnitude of the $\mathrm{CO}_{2}$ sink/source in the contemporary ocean (see their Figure 3a) are in good agreement with our results in the "Annual" panel in Figure 5. The Ocean GCM results obtained by Lenton and Matear (2007) also exhibit a strong
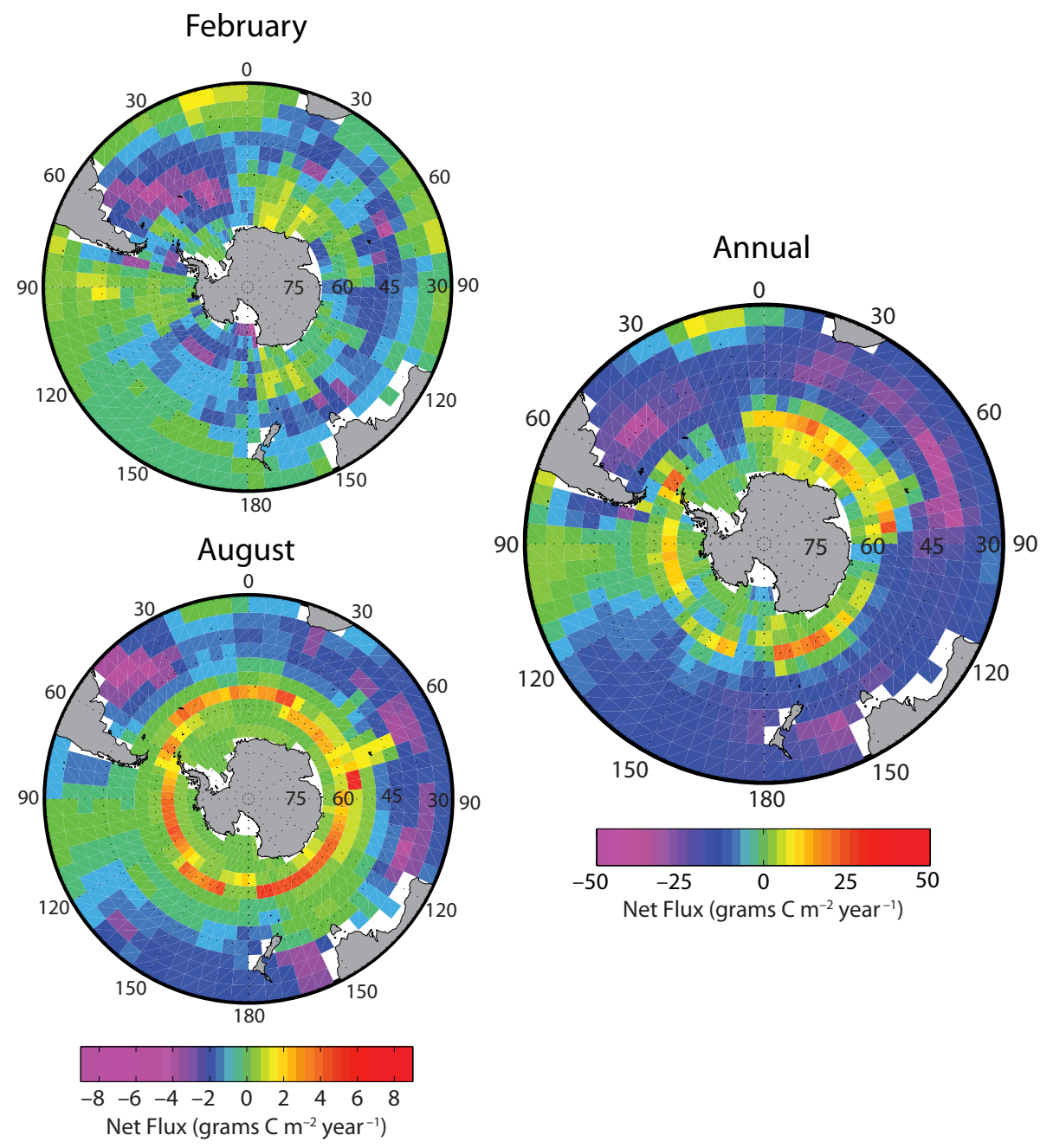

Figure 5. Distribution of climatological mean sea-air $\mathrm{CO}_{2}$ flux in the reference year 2000 for February and August, along with the annual mean. See text for the assumptions used for estimating the flux in the sea ice fields. The source zone is indicated with yellow and orange, the sink zone with blue and magenta, and the neutral (small flux) zone with green.
$\mathrm{CO}_{2}$ sink zone around $40^{\circ} \mathrm{S}$. However, the distribution patterns are somewhat different from our results: the sink zone is strongest in the Pacific and Indian Ocean sectors, while it is much weaker in the Atlantic sector.

\section{CHANGE OF THE SOUTHERN OCEAN $\mathrm{CO}_{2}$ SINK/SOURCE}

Whether the $\mathrm{CO}_{2}$ sink intensity in the Southern Ocean has changed in recent decades in response to increasing atmospheric loading of $\mathrm{CO}_{2}$ and 
climate change is an important question. This issue has been addressed actively in recent GCM studies. Le Quéré et al. (2007) inverted the atmospheric $\mathrm{CO}_{2}$ concentration data from 12 stations located south of $30^{\circ} \mathrm{S}$ to obtain sea-air $\mathrm{CO}_{2}$ flux, and observed that the Southern Ocean $\mathrm{CO}_{2}$ sink weakened during 1981-2004. They attributed this weakening to the increase in upwelling of deep waters caused by stronger winds during this period. Le Quéré et al. (2010) used a forward Ocean GCM coupled with a marine biogeochemistry model to investigate the contributions of temperature, atmospheric $\mathrm{CO}_{2}$, wind regimes, and heat-water flux to the sea-air $\mathrm{CO}_{2}$ flux using three different wind products. They found that regional differences in the annual rates for sea-air $\mathrm{pCO}_{2}$ change developed only when the model was driven using both increasing atmospheric $\mathrm{CO}_{2}$ and changing climate. Their model study yielded a mean decadal rate of $\Delta p \mathrm{CO}_{2}$ change of about $20 \mu$ atm decade ${ }^{-1}$, which is about $4 \mu$ atm decade ${ }^{-1}$ faster than the mean atmospheric $\mathrm{CO}_{2}$ increase rate of about $16 \mu$ atm decade ${ }^{-1}$ for their study period of 1981-2007. Lenton and Matear (2007) and Lovenduski et al. (2007) used Biogeochemistry-Ocean GCMs to explore the relationship between the SAM and changes in the Southern Ocean $\mathrm{CO}_{2}$ flux. These investigators found that the southward shift and the intensification of zonal winds that occurred during the positive trend of SAM for the past several decades caused an increase in deepwater upwelling, which in turn increased surface water $p \mathrm{CO}_{2}$ and decreased $\mathrm{CO}_{2}$ sink intensity. The magnitudes of changes estimated by these model studies are broadly in agreement.
Circumpolar Open Water Zone

To document how the primary driving force of $\mathrm{CO}_{2}$ uptake over the Southern Ocean has changed in recent decades, we analyzed the wintertime data for surface water $p \mathrm{CO}_{2}$ in the open ocean water zone, which includes the AAIW formation areas. Because biological activities are minimal and the vertical mixing of water is expected to be maximal during the winter months, the trend in winter surface water $p \mathrm{CO}_{2}$ should indicate the trends in vertical mixing and possibly meridional transport rate. Furthermore, the time trend must be evaluated based on the $p \mathrm{CO}_{2}$ time-series values of a similar water mass or type. We have chosen wintertime SST as the indicator, and divided the data into five temperature zones between $0.8^{\circ} \mathrm{C}$ and $5.5^{\circ} \mathrm{C}$. Figure 6 shows the time plots and data locations, and Table 1 summarizes the results of linear regression analysis for $p \mathrm{CO}_{2}$ and SST in each zone. The $p \mathrm{CO}_{2}$ rates that are corrected for changes in SST are also listed. While the rates for the coldest and warmest zones $\left(0.80^{\circ}-1.5^{\circ} \mathrm{C}\right.$ and $4.5^{\circ}-5.5^{\circ} \mathrm{C}$, respectively) are similar to the atmospheric rate, the middle three zones $\left(1.5^{\circ}-4.5^{\circ} \mathrm{C}\right.$, about $50^{\circ}-55^{\circ} \mathrm{S}$ ) have significantly faster rates $\left(23.9 \pm 3.8 \mu\right.$ atm decade $\left.{ }^{-1}\right)$ than the atmospheric rate of about $16 \mu$ atm decade ${ }^{-1}$, indicating that the ocean $\mathrm{CO}_{2}$ uptake is weakening. The faster increase in seawater $p \mathrm{CO}_{2} \mathrm{com}$ pared to atmospheric $p \mathrm{CO}_{2}$ means that this zone, which had been a sink for atmospheric $\mathrm{CO}_{2}$ since the beginning of our measurements in the 1960s, changed to a source some time after 2005. In 1960, the atmospheric $p \mathrm{CO}_{2}$ was about $310 \mu$ atm $\left(\mathrm{CO}_{2}\right.$ concentration in dry air of 316 ppm corrected for the barometric pressure and water vapor), whereas the seawater $p \mathrm{CO}_{2}$ was between 275 and $300 \mu$ atm, 10 to $35 \mu$ atm below the atmospheric. In contrast, the atmospheric $p \mathrm{CO}_{2}$ was about $377 \mu$ atm (385 ppm CO $\mathrm{CO}_{2}$ in dry air) in 2010 , and the seawater $p \mathrm{CO}_{2}$ was 375 to $385 \mu \mathrm{atm}$, equal or slightly greater than the atmospheric value.

Importantly, this temperature zone corresponds to the formation region for the AAIW, and the observed high rate of $p \mathrm{CO}_{2}$ increase suggests a reduction of the $\mathrm{CO}_{2}$ sink intensity for AAIW due to an increase in upwelling of $\mathrm{CO}_{2}$-rich deep waters. Although the validity of the eddy mixing parameterizations used in the ocean model studies has been questioned by Böning et al. (2008) and Downs et al. (2011), Le Quéré et al's (2010) estimate of $20 \mu \mathrm{atm}$ decade $^{-1}$ (when the model results are sampled at the same location and time as the observations) is consistent with our observations.

Changes in the intense $\mathrm{CO}_{2}$ sink zone centered around $40^{\circ} \mathrm{S}$ are clearly important for projecting future global ocean $\mathrm{CO}_{2}$ uptake. However, presently available $p \mathrm{CO}_{2}$ data are not extensive enough to address this issue reliably. For example, Metzl (2009) investigated changes in the intense $\mathrm{CO}_{2}$ sink zone in the southern Indian Ocean and reported a 1991-2007 mean winter rate of increase ranging between $36 \pm 4$ and $47 \pm 10 \mu$ atm decade ${ }^{-1}$ (corrected for SST change) in the southern half of the sink zone between $40^{\circ} \mathrm{S}$ and $55^{\circ} \mathrm{S}$; this indicates a weakening of the sink intensity due to much faster rates of oceanic $p \mathrm{CO}_{2}$ increase than the atmospheric rate of $16 \mu$ atm decade ${ }^{-1}$. On the other hand, a much lower rate of $6 \mu$ atm $\mathrm{yr}^{-1}$ was 
Winter $p \mathrm{CO}_{2}$ Data Year Days: 172 to 326 Lat $\leq-50$

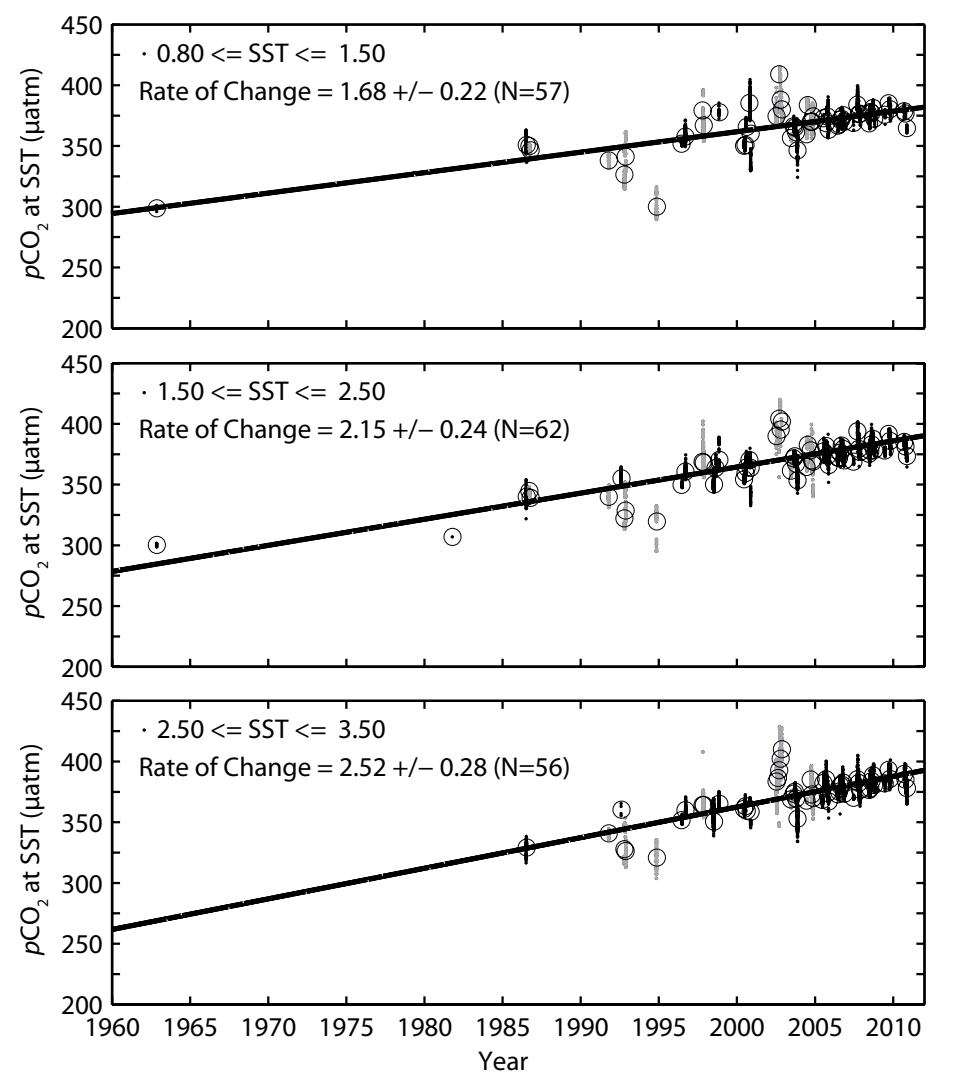

Surface $p \mathrm{CO}_{2}$ Winter (Day 172-326) 1981-2010

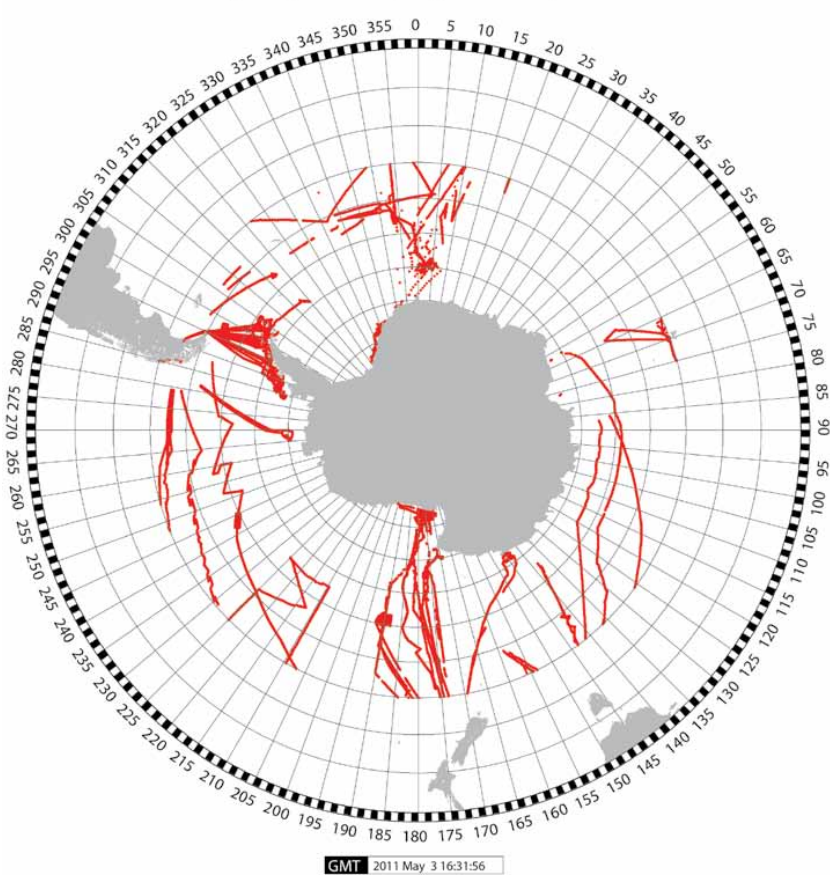

Figure 6. Sample locations and the time trend of surface water $p \mathrm{CO}_{2}$ data during the winter months (year days 172-326). The mean rate of change is shown with the heavy black linear regression line and the values in the unit of $\mu a t m \mathrm{yr}^{-1}$. The data collected during the El Niño and non-El Niño periods are shown, respectively, with gray and black dots. The open circles are monthly means, used for linear regression calculations. The data are available at CDIAC. From Takahashi et al. (2011)

Table 1. The mean decadal rate of change for wintertime surface water $p \mathrm{CO}_{2}$ and sea surface temperature (SST) in five temperature zones. The second column shows the mean rate of $p \mathrm{CO}_{2}$ change as observed in Figure 6, and the SST change in the third column is estimated using the temperature data obtained concurrently with the $\mathrm{pCO}_{2}$ data. The fourth column shows

the $p \mathrm{CO}_{2}$ change corrected for the SST change using $4.23 \% p \mathrm{CO}_{2}$ change per ${ }^{\circ} \mathrm{C}$.

\begin{tabular}{|c|c|c|c|c|c|}
\hline $\begin{array}{c}\text { SST } \\
\text { Range }\left({ }^{\circ} \mathrm{C}\right)\end{array}$ & $\begin{array}{l}p \mathrm{CO}_{2} \text { Change } \\
\mu \mathrm{atm} \text { decade }^{-1} \\
(1986-2010)\end{array}$ & $\begin{array}{l}\text { SST Change } \\
{ }^{\circ} \mathrm{C} \text { decade }^{-1} \\
(1986-2010)\end{array}$ & $\begin{array}{c}p \mathrm{CO}_{2} \text { Change } \\
\text { corrected for SST } \\
\mu \text { atm decade }{ }^{-1}\end{array}$ & $\begin{array}{l}\text { No. of } \\
\text { Months }\end{array}$ & $\begin{array}{l}\text { Data } \\
\text { Counts }\end{array}$ \\
\hline $0.80-1.50$ & $16.8 \pm 2.9$ & $-0.031 \pm 0.021$ & $17.3 \pm 3.2$ & 56 & 4,668 \\
\hline $1.50-2.50$ & $23.8 \pm 3.0$ & $+0.020 \pm 0.028$ & $23.5 \pm 3.4$ & 61 & 9,326 \\
\hline $2.50-3.50$ & $25.2 \pm 2.8$ & $+0.13 \pm 0.038$ & $23.3 \pm 3.4$ & 56 & 12,473 \\
\hline $3.50-4.50$ & $24.3 \pm 4.2$ & $-0.045 \pm 0.036$ & $24.9 \pm 4.7$ & 59 & 19,163 \\
\hline $4.50-5.50$ & $16.7 \pm 2.8$ & $+0.031 \pm 0.034$ & $16.2 \pm 3.3$ & 59 & 24,114 \\
\hline -..........-. & -.............- & -................ & -............. & ...- & -.......- \\
\hline $0.80-5.50$ & $21.4 \pm 4.2$ & $0.02 \pm 0.03$ & $21.0 \pm 3.4$ & 288 & 69,744 \\
\hline $1.50-4.50$ & $24.4 \pm 3.3$ & $0.04 \pm 0.09$ & $23.9 \pm 3.8$ & 176 & 40,962 \\
\hline
\end{tabular}


observed in the northern half between $35^{\circ} \mathrm{S}$ and $40^{\circ} \mathrm{S}$, suggesting an increase in sink intensity. More observations are needed to document the change in this important sink zone.

\section{CONCLUSION}

The global ocean is currently absorbing annually about $2 \mathrm{Pg} \mathrm{C} \mathrm{yr}^{-1}$ of $\mathrm{CO}_{2}$ from the air, and it plays a significant role in the uptake and long-term storage of anthropogenic $\mathrm{CO}_{2}$ that is emitted to the atmosphere, affecting Earth's climate. The climatological mean sea-air flux is estimated by the observed sea-air $p \mathrm{CO}_{2}$ difference and the gas transfer rate parameterized as a function of (wind speed) ${ }^{2}$. A Southern Ocean zone between $30^{\circ} \mathrm{S}$ and $50^{\circ} \mathrm{S}$ is found to be a major sink for atmospheric $\mathrm{CO}_{2}$, tak-

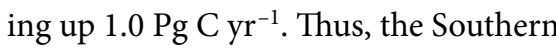
Ocean is a major ocean sink for atmospheric $\mathrm{CO}_{2}$. This paper discusses how this $\mathrm{CO}_{2}$ sink is changing in response to recent climate change.

We investigated the multidecadal mean trends for surface water $p \mathrm{CO}_{2}$ and temperature $\left(0.8^{\circ}-5.5^{\circ} \mathrm{C}\right)$ during winter in the formation region for AAIW. The wintertime waters were chosen because of minimal winter biological activity in order to avoid large biologically induced variability in seawater $p \mathrm{CO}_{2}$, and because of the maximal vertical mixing. The $p \mathrm{CO}_{2}$ in the waters between $1.5^{\circ} \mathrm{C}$ and $4.5^{\circ} \mathrm{C}$ has increased at a rate of $23.9 \pm 3.8 \mu$ atm decade ${ }^{-1}$, which is faster than the rate of atmospheric $p \mathrm{CO}_{2}$ increase of about $16 \mu$ atm decade $\mathrm{de}^{-1}$. This suggests weakening $\mathrm{CO}_{2}$ sink intensity for AAIW, which transports water to depths of about $900 \mathrm{~m}$. The rate of change in the intense $\mathrm{CO}_{2}$ sink zone centered at about $40^{\circ} \mathrm{S}$ is clearly important, but it cannot be determined reliably due to limited observations. The observed distribution and the mean rate of change in surface water $p \mathrm{CO}_{2}$ of the Southern Ocean are generally in agreement with the results of the BiogeochemistryOcean GCM studies.

\section{ACKNOWLEDGMENTS}

This study was supported by grants from NOAA (NA080AR4320754) and NSF (ANT06-36879). We benefited greatly from advice offered by Douglas Martinson, Stanley Jacobs, and Arnold L. Gordon of Lamont-Doherty Earth Observatory. We gratefully acknowledge the dedicated operational assistance provided by the ships' captains and crews aboard the research vessels Nathaniel $B$. Palmer, Laurence M. Gould, Akademik Ioffe, Marion-Dufresne, and other ships, who helped us to make observations. We are particularly grateful for valuable technical assistance provided by Raytheon Antarctic Services. Dd

\section{REFERENCES}

Arrigo, K.R., and D.N. Thomas. 2004. Large scale importance of sea ice biology in the Southern Ocean. Antarctic Science 16(4):471-486, http:// dx.doi.org/10.1017/S0954102004002263.

Arrigo, K.R., and G.L. van Dijken. 2007. Interannual variation in air-sea flux in the Ross Sea, Antarctica: A model analysis. Journal of Geophysical Research 112, http:// dx.doi.org/10.1029/2006JC003492.

Bakker, D.C.E., M. Hoppema, M. Schröder, W. Geibert, and H.J.W. de Baar. 2008. A rapid transition from ice covered $\mathrm{CO}_{2}$-rich waters to a biologically mediated $\mathrm{CO}_{2}$ sink in the eastern Weddell Gyre. Biogeosciences Discussions 5:1,205-1,235, http://dx.doi.org/10.5194/ bgd-5-1205-2008.

Bakker, D.C.E., H.J.W. de Baar, and U.V. Bathmann. 1997. Changes of carbon dioxide in surface waters during spring in the Southern Ocean. Deep-Sea Research Part II 44:91-127, http:// dx.doi.org/10.1016/S0967-0645(96)00075-6.

Bates, N.R., D.A. Hansell, C.A. Carlson, and L.I. Gordon. 1998. Distribution of $\mathrm{CO}_{2}$ species, estimates of net community production and sea-air $\mathrm{CO}_{2}$ exchange in the Ross Sea polynya. Journal of Geophysical Research 103(C2):2,883-2,896, http:// dx.doi.org/10.1029/97JC02473.

Bender, M.L., D.T. Ho, M.B. Hendricks, R. Mika, M.O. Battle, P.P. Tans, T.J. Conway, B. Sturtevant, and N. Cassar. 2005. Atmospheric $\mathrm{O}_{2} / \mathrm{N}_{2}$ changes, 1993-2002: Implications for the partitioning of fossil fuel $\mathrm{CO}_{2}$ sequestration. Global Biogeochemical Cycles 19, GB4017, http://dx.doi.org/10.1029/2004GB002410.

Böning, C.W., A. Disper, M. Visbeck, S.R. Rintoul, and F.U. Schwartzkopf. 2008. The response of the Antarctic Circumpolar Current to recent climate change. Nature Geoscience 1:864-869, http://dx.doi.org/10.1038/ngeo362.

Boutin, J., L. Merlivat, C. Henocq, N. Martin, and J.B. Sallee. 2008. Air-sea $\mathrm{CO}_{2}$ flux variability in frontal regions of the Southern Ocean from CARbon Interface OCean Atmosphere drifters. Limnology and Oceanography 53(5, part 2):2,062-2,079, http://dx.doi.org/10.4319/ lo.2008.53.5_part_2.2062.

Chipman, D.W., J. Marra, and T. Takahashi. 1993. Primary production at $47^{\circ} \mathrm{N}$ and $20^{\circ} \mathrm{W}$ in the North Atlantic Ocean: A comparison between the ${ }^{14} \mathrm{C}$ incubation method and the mixed layer carbon budget. Deep-Sea Research Part II 40(1/2):151-169, http:// dx.doi.org/10.1016/0967-0645(93)90011-B.

Dong, S., J. Sprintall, S.T. Gille, and L. Talley. 2008. Southern Ocean mixed-layer depth from Argo float profiles. Journal of Geophysical Research 113, C06013, http://dx.doi.org/ 10.1029/2006JC004051.

Downs, S.M., A. Gnanadesikan, S. Griffies, and J.L. Sarmiento. 2011. Water mass exchange in the Southern Ocean in coupled climate models. Journal of Physical Oceanography 41:1,756-1,771, http://journals. ametsoc.org/doi/abs/10.1175/2011jpo4586.1.

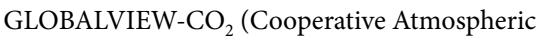
Data Integration Project - Carbon Dioxide). 2006. CD-ROM, NOAA CMDL, Boulder, Colorado. (Also available on Internet via anonymous FTP to ftp.cmdl.noaa.gov, Path: $\mathrm{ccg} / \mathrm{co} 2 /$ GLOBALVIEW.)

Gruber, N., M. Gloor, S.E. Mikaloff Fletcher, S.C. Doney, S. Dutkeiwicz, M.J. Follows, M. Gerber, A.R. Jacobson, F. Joos, K. Lindsay, and others. 2009. Oceanic sources, sinks, and transport of atmospheric $\mathrm{CO}_{2}$. Global Biogeochemical Cycles 23, GB1005, http:// dx.doi.org/10.1029/2008GB003349.

Gurney, K.R., D. Baker, P. Rayner, A.S. Denning, and TransCom 3 L2 modelers. 2008. Interannual variations in regional net carbon exchange and sensitivity to observing networks estimated from atmospheric $\mathrm{CO} 2$ inversions for the period 1979 to 2006. Global Biogeochemical Cycles, 22, GB3025, http:// dx.doi.org/10.1029/2007GB003082. 
Hales, B., D.W. Chipman, and T. Takahashi. 2004. High-frequency measurement of partial pressure and total concentration of carbon dioxide in seawater using microporous hydrophobic membrane contactors. Limnology and Oceanography Methods 2:356-364, http:// dx.doi.org/10.4319/lom.2004.2.91.

Hales, B., and T. Takahashi. 2004. Highresolution biogeochemical investigation of the Ross Sea, Antarctica, during the AESOPS (U.S. JGOFS) Program. Global Biogeochemical Cycles 18, GB3006, http://dx.doi.org/ 10.1029/2003GB002165.

Jacobson, A.R., S.E. Mikaloff Fletcher, N. Gruber, J.L. Sarmiento, and M. Gloor. 2007. A joint atmosphere-ocean inversion for surface fluxes of carbon dioxide. Part 2: Regional results. Global Biogeochemical Cycles 21, GB1020, http://dx.doi.org/10.1029/2006GB002703.

Kanamitsu, M., W. Ebisuzaki, J. Woollen, S.-K. Yang, J.J. Hnilo, M. Fiorino, and G.L. Potter. 2002. NCEP-DOE AMIP-II Reanalysis (R-2). Bulletin of the American Meteorological Society 83:1,631-1,643. (The updated data to 2005 were downloaded on March 22, 2005, from ftp://ftp.cdc.noaa.gov/ Datasets/ncep.reanalysis2/gaussian.grid.)

Le Quéré, C., C. Rodembeck. E. Buitenhuis, T. Conway, R. Langenfelds, A. Gomez, C. Labuschagne, M. Ramonet, T. Nakazawa, N. Metzl, and others. 2007. Saturation of the Southern Ocean $\mathrm{CO}_{2}$ sink due to recent climate change. Science 316:1,735-1,738, http:// dx.doi.org/10.1126/science.1136188.

Le Quéré, C., T. Takahashi, E.T. Buitenhuis, C. Rodenbeck, and S.C. Sutherland. 2010. Impact of climate change and variability on the global oceanic sink of $\mathrm{CO}_{2}$. Global Biogeochemical Cycles 24, GB4007, http:// dx.doi.org/10.1029/2009GB003599.

Lenton, A., and R.J. Matear. 2007. Role of the Southern Annular Mode (SAM) in Southern Ocean $\mathrm{CO}_{2}$ uptake. Global Biogeochemical Cycles 21, GB2016, http://dx.doi.org/10.1029/ 2006GB002714.

Lizotte, M.P. 2001. The contributions of sea ice algae to Antarctic marine primary production. American Zoologist 41:57-71, http://dx.doi.org/ 10.1093/icb/41.1.57.

Lovenduski, N.S., N. Gruber, S.C. Doney, and I.D. Lima. 2007. Enhanced $\mathrm{CO}_{2}$ outgassing in the Southern Ocean from a positive phase of the Southern Annual Mode. Global Biogeochemical Cycles 21, GB2026, http:// dx.doi.org/10.1029/2006GB002900.

Manning, A.C., and R.F. Keeling. 2006. Global oceanic and land biotic carbon sinks from the Scripps atmospheric oxygen flask sampling network. Tellus 58B:95-116, http://dx.doi.org/ 10.1111/j.1600-0889.2006.00175.x.
Metzl, N., C. Brunet, A. Jabaud-Jan, A. Poisson, and B. Schauer. 2006. Summer and winter airsea $\mathrm{CO}_{2}$ fluxes in the Southern Ocean. Deep Sea Research Part I 53:1,548-1,563, http:// dx.doi.org/10.1016/j.dsr.2006.07.006.

Metzl, N. 2009. Decadal increase of oceanic carbon dioxide in Southern Indian Ocean surface waters (1991-2007). Deep Sea Research Part II 56:607-619, http://dx.doi.org/10.1016/ j.dsr2.2008.12.007.

Mikaloff Fletcher, S.E., N. Gruber, A.R. Jacobson, S.C. Doney, S. Dutkiewicz, M. Gerber, M. Follows, F. Joos, K. Lindsay, D. Menemenlis, and others. 2006. Inverse estimates of anthropogenic $\mathrm{CO}_{2}$ uptake, transport, and storage by the ocean. Global Biogeochemical Cycles 20, GB2002, http://dx.doi.org/10.1029/ 2005GB002530.

Moore, J.K., and M.R. Abbott. 2000. Phytoplankton chlorophyll distributions and primary production in the Southern Ocean. Journal of Geophysical Research 105:28,709-28,722, http:// dx.doi.org/10.1029/1999JC000043.

NCEP/DOE 2 Reanalysis Data. 2005. Ice field data provided by NOAA/OAR/ESRL PSD, Boulder CO, via web site: http://www.esrl.noaa. gov/psd/data/gridded/data.ncep.reanalysis2. gaussian.html.

Newberger, T. 2004. Underway $p \mathrm{CO}_{2}$ System Users Manual, Palmer $2004 p \mathrm{CO}_{2}$ System. LamontDoherty Earth Observatory, Palisades, NY, 23 pp., http://www.ldeo.columbia.edu/res/ $\mathrm{pi} / \mathrm{CO} 2 /$ carbondioxide/text/Palmer_PCO2_ man_1_2.pdf.

Orsi, A.H., T. Whitworth III, and W.D. Nowlin. 1995. On the meridional extent and fronts of the Antarctic Circumpolar Current. Deep Sea Research Part I 42:641-673, http:// dx.doi.org/10.1016/0967-0637(95)00021-W.

Quay, P., R. Sommerup, T. Westby, J. Sutsman, and A. McNichol. 2003. Changes in the ${ }^{13} \mathrm{C} /{ }^{12} \mathrm{C}$ of dissolved inorganic carbon in the ocean as a tracer of anthropogenic $\mathrm{CO}_{2}$ uptake. Global Biogeochemical Cycles 17(1), 1004, http:// dx.doi.org/10.1029/2001GB001817.

Rubin, S.I. 2003. Carbon and nutrient cycling in the upper water column across the Polar Frontal Zone and Antarctic Circumpolar Current along $170^{\circ} \mathrm{W}$. Global Biogeochemical Cycles 17, 1087, http://dx.doi.org/10.1029/2002GB001900.

Rubin, S.I., T. Takahashi, D.W. Chipman, and J.G. Goddard. 1998. Primary production and nutrient utilization ratios in the Pacific Sector of the Southern Ocean based on seasonal changes in seawater chemistry. Deep Sea Research 45:1,211-1,234, http://dx.doi.org/ 10.1016/S0967-0637(98)00021-1.

Sabine, C.L., R.A. Feely, N. Gruber, R.M. Key, K. Lee, J.L. Bullister, R. Wanninkhof, C.S. Wong, D.W.R. Wallace, B. Tilbrook, and others. 2004.
The oceanic sink for anthropogenic $\mathrm{CO}_{2}$. Science 305:367-371, http://dx.doi.org/10.1126/ science.1097403.

Sarmiento, J.L., and N. Gruber. 2006. Ocean Biogeochemical Dynamics. Princeton University Press, Princeton, NJ, 503 pp.

Signorini, S.R., and C.R. McClain. 2009. Effect of uncertainties in climatologic wind, ocean $p \mathrm{CO}_{2}$, and gas transfer algorithms on the estimate of global sea-air $\mathrm{CO}_{2}$ flux. Global Biogeochemical Cycles 23, GB2025, http:// dx.doi.org/10.1029/2008GB003246.

Sweeney, C. 2003. The annual cycle of surface $\mathrm{CO}_{2}$ and $\mathrm{O}_{2}$ in the Ross Sea: A model for gas exchange on the continental shelves of Antarctica. Pp. 295-312 in Biogeochemistry of the Ross Sea. G.R. DiTullio and R.B. Dunbar, eds, Antarctic Research Series, vol. 78, American Geophysical Union, Washington, DC, http://dx.doi.org/10.1029/AR078.

Sweeney, C., E. Gloor, A.R. Jacobson, R.M. Key, G. McKinley, J.L. Sarmiento, and R. Wanninkhof. 2007. Constraining global air-sea gas exchange for $\mathrm{CO}_{2}$ with recent bomb ${ }^{14} \mathrm{C}$ measurements. Global Biogeochemical Cycles 21, GB2015, http://dx.doi.org/10.1029/ $2006 \mathrm{~GB} 002784$.

Takahashi, T., and D.W. Chipman. 2012. $\mathrm{CO}_{2}$ transport in deep waters off Wilkes Land. Oceanography 25(3):24-25, http://dx.doi.org/ 10.5670/oceanog.2012.70.

Takahashi, T., S.C. Sutherland, R. Wanninkhof, C. Sweeney, R.A. Feely, D.W. Chipman, B. Hales, G. Friederich, F. Chavez, C. Sabine, and others. 2009. Climatological mean and decadal changes in surface ocean $p \mathrm{CO}_{2}$, and net sea-air $\mathrm{CO}_{2}$ flux over the global oceans. Deep Sea Research Part II 56: 554-577, http:// dx.doi.org/10.1016/j.dsr2.2008.12.009.

Takahashi, T., S.C. Sutherland, and A. Kozyr. 2011. Global Ocean Surface Water Partial Pressure of $\mathrm{CO}_{2}$ Database: Measurements Performed During 1957-2010 (Version 2010). ORNL/CDIAC-159, NDP-088(V2010). Carbon Dioxide Information Analysis Center, Oak Ridge National Laboratory, U.S. Department of Energy, Oak Ridge, Tennessee, http://dx.doi.org/10.3334/ CDIAC/otg.ndp088(V2010).

Wanninkhof, R. 1992. Relationship between wind speed and gas exchange. Journal of Geophysical Research 97:7,373-7,382, http://dx.doi.org/ 10.1029/92JC00188.

Weiss, R.F. 1974. Carbon dioxide in water and seawater: The solubility of a non-ideal gas. Marine Chemistry 2:203-215, http:// dx.doi.org/10.1016/0304-4203(74)90015-2.

Worby, A.P., C.A. Geiger, M.J. Paget, M.L. Van Woert, S.F. Ackley, and T.L. DeLiberty. 2008. Thickness distribution of Antarctic sea ice. Journal of Geophysical Research 113, C05S92, http://dx.doi.org/10.1029/2007JC004254. 